\title{
Evaluation of one hundred and one instrumented bridges suggests a new level of inspection should be established in the bridge design codes
}

\author{
Baidar Bakht ${ }^{1} \cdot$ Aftab $_{\text {Mufti }^{1}}$ (D)
}

Received: 17 October 2017/ Accepted: 20 October 2017/Published online: 20 November 2017

(c) Springer-Verlag GmbH Germany 2017

During the past 40 years, the authors and their close colleagues have been involved in evaluating the load carrying capacities of bridges through instrumentation and testing. This note summarises the major outcomes of tests on 101 bridges [1]. Most of these tests are reported in published documents, which are provided in the report. Details of the remaining few tests are stored in files that are still in the custody of the authors. Of the 101 bridges, 3 were tested for their ultimate load carrying capacities, 16 were tested to confirm their behaviour, and 82 were proof tested to determine their optimum load carrying capacities. The summaries of the various types of tests are given in Table 1.

As can be seen in Table 1, it was found that 66 of the 82 proof-tested bridges, i.e. $75 \%$, had higher load carrying capacities than could be predicted by analytical evaluations. This note has been compiled to suggest that the evaluation of the load carrying capacities of bridges through instrumentation and structural health monitoring be formally recognised by the Canadian Highway Bridge Design Code (CHBDC), a section of which deals directly with the evaluation of bridges. According to this section, the truck loads permitted on a bridge depend upon the level
Table 1 Summary of 101 tests

\begin{tabular}{llllll}
\hline Type of & Ultimate & Behaviour & Proof & & \\
\cline { 3 - 5 } & & & $\begin{array}{l}\text { Upgrade } \\
\text { or } \\
\text { remove } \\
\text { posting }\end{array}$ & $\begin{array}{l}\text { Downgrade } \\
\text { or keep } \\
\text { posting }\end{array}$ & Repair \\
\hline $\begin{array}{l}\text { No. of } \\
\text { bridges }\end{array}$ & 3 & 16 & 66 & 12 & 4 \\
\hline
\end{tabular}

of confidence on the condition of the bridge, which is currently determined mostly by visual inspection. It is proposed that another level of inspection through instrumentation be added to the CHBDC so that capacities of existing bridge are utilised optimally.

\section{Reference}

1. Bakht B, Mufti A (2017) Evaluation of one hundred and one instrumented bridge. Research report August 2017, Structural Innovation and Monitoring Technologies Resource Centre (SIMTREC), University of Manitoba, Manitoba, Canada
Aftab Mufti

aftab.mufti@umanitoba.ca

1 Structural Innovation and Monitoring Technology Resource Centre, University of Manitoba, A250 Agricultural and Civil Engineering Building, 96 Dafoe Road, Winnipeg, MB, Canada 